\title{
Occupational health hazards and causative factors of male adult bonded labourers of South India: a mixed method pilot study
}

\author{
A. Arunkumar* \\ Department of Psychiatry, Government Stanley Medical College and Hospital, Chennai 600001, India \\ Received: 20 January 2016 \\ Revised: 19 February 2016 \\ Accepted: 20 February 2016 \\ *Correspondence: \\ Dr. A. Arunkumar, \\ E-mail: arunkoc2003@gmail.com \\ Copyright: () the author(s), publisher and licensee Medip Academy. This is an open-access article distributed under \\ the terms of the Creative Commons Attribution Non-Commercial License, which permits unrestricted non-commercial \\ use, distribution, and reproduction in any medium, provided the original work is properly cited.
}

\begin{abstract}
Background: Global slavery index estimates 35.9 million people in slavery today. There are no published studies that explore the various health issues faced by bonded laborers, their health seeking behavior, their access to healthcare facilities and healthcare providers.

Methods: From January 2008 to March 2008, we developed a 61-item questionnaire that captures information on: socio-demographic characteristics, anthropometry, debt/bondage, work culture, socio-economic conditions and health status of the bonded labourers. The questionnaire was field tested and revised. Simultaneously a topic guide was developed for in-depth interviewing of selected participants. From April 2008 to July 2008, a total of 50 male adult bonded labourers were purposively sampled and recruited through the international non-governmental organization in Tiruvallur and Chengalpattu districts of Tamilnadu and Nagiri on the border of Tamil Nadu- Andhra Pradesh. Participants were from more than 35 rice mills and brick kilns of Tamil Nadu and Andhra-Pradesh. Twenty participants were selected for in-depth interviewing to expand on and explain the quantitative findings by listening to the narratives and lived experiences of these participants supplemented by five interviews from key informants who closely worked with the bonded laborers.

Results: They face numerous health hazards owing to their slavery. It is observed that they do not have acceptable living conditions with very low salary, poor sanitary conditions, and inadequate knowledge of healthy life styles and low accessibility to health care providers.

Conclusions: Structural and institutional policies are required to address the health issues of these bonded labourers. More studies are necessary to gain more insight on the health hazards faced by the bonded labourers of other parts of the country.
\end{abstract}

Keywords: Bonded laborers, Mixed methods, Occupational health hazards, Tamil Nadu

\section{INTRODUCTION}

Global slavery index estimates 35.9 million people in slavery today (global slavery). ${ }^{1}$ A $26 \%$ of them is represented by children (international labour organisation). ${ }^{2}$ The largest number of slavery is in India, estimated between 10.7 and 12.7 million (Kara). ${ }^{3}$ Forced labour and slavery is marked by physical and sexual assault with documented cases of being beaten, gang raped, locked in tiny rooms, starved and even killed. There are cases of victims escaping but being tracked down, beaten and returned to the facility. Most of them do not even try to run away as the owners use fear and deception tactics to trap them more strongly than physical bondage.

There are no published studies that explore the various health issues faced by bonded labourers, their health seeking behaviour, their access to healthcare facilities and healthcare providers. There are no studies or research undertaken in India that specifically addresses the health issues of the male adult bonded labourers. This calls 
attention towards the need for a formative research that specifically captures the physical and psychological health status, atmosphere of their working conditions, their effect on health and future implications in providing comprehensive healthcare to this hard-to-reach population.

We used a sequential mixed methods approach to understand their health status, socio-economic conditions and explored various reasons behind their current health status and the connection with their socio-economic conditions.

\section{METHODS}

From January 2008 to March 2008, we interacted with the representatives of the released bonded labourers, government officials and an international NGO working with them. We developed a 61-item questionnaire that captures information on: socio-demographic characteristics, anthropometry, debt/bondage, work culture, socio-economic conditions and health status. The questionnaire was field tested and revised. Simultaneously a topic guide was developed for in-depth interviewing of selected participants. From April 2008 to July 2008, a total of 50 male adult bonded labourers were purposively sampled and recruited through the international non-governmental organization in Tiruvallur and Chengalpattu districts of Tamilnadu and Nagiri on the border of Tamil Nadu- Andhra Pradesh. All these people were released by the joint effort of the NGOs, police and legal Professionals. Participants were from more than 35 rice mills and brick kilns of Tamil Nadu and Andhra-Pradesh. Informed consent was obtained from the participants. After the administration of the questionnaire, 20 participants were selected for in-depth interviewing to expand on and explain the quantitative findings by listening to the narratives and lived experiences of these participants supplemented by five interviews from Key informants who closely worked with the bonded labourers. A professional translator was employed in places where Telugu was spoken. Quantitative surveys were analysed using Epi Info ${ }^{\mathrm{TM}}$ and the in-depth interviews were transcribed as extended notes, translated and were initially explored using focused coding and constant comparative method. ${ }^{4,5}$ Few emergent codes and categories were identified from the text and added to the existing codes gained from observational studies. Axial coding was done to develop connections between categories derived from all data. Themes were identified by looking for similarities, differences and relationships between categories. ${ }^{6}$

\section{RESULTS}

\section{Participant characteristics}

Quantitative survey: Tiruvallur ( $\mathrm{n}=17,34 \%)$ and Chengalpattu $(n=16,32 \%)$ districts of Tamilnadu and Nagiri $(n=17,34 \%)$.

\section{Qualitative interviews}

Table 1: Socio-demographic characteristics.

\begin{tabular}{|c|c|c|}
\hline Variable & $\begin{array}{l}\text { Quantitative } \\
(\mathbf{N}=50)\end{array}$ & $\begin{array}{l}\text { Qualitative } \\
(\mathbf{N}=20)\end{array}$ \\
\hline $\begin{array}{l}\text { Age } \\
<20 \\
20-30 \\
31-40 \\
41-50 \\
>50\end{array}$ & $\begin{array}{l}3(6 \%) \\
19(38 \%) \\
16(32 \%) \\
8(16 \%) \\
4(8 \%)\end{array}$ & $\begin{array}{l}\text { Mean age } \\
27.2 \text { years }\end{array}$ \\
\hline $\begin{array}{l}\text { Mother tongue } \\
\text { Tamil } \\
\text { Telugu }\end{array}$ & $\begin{array}{l}6(12 \%) \\
44(88 \%)\end{array}$ & $\begin{array}{l}12(60 \%) \\
8(40 \%)\end{array}$ \\
\hline $\begin{array}{l}\text { Education } \\
\text { Uneducated } \\
\text { Primary } \\
\text { Middle }\end{array}$ & $\begin{array}{l}41(82 \%) \\
6(12 \%) \\
3(6 \%)\end{array}$ & $\begin{array}{l}9(45 \%) \\
8(40 \%) \\
3(15 \%)\end{array}$ \\
\hline $\begin{array}{l}\text { Occupation } \\
\text { Unskilled worker }\end{array}$ & $50(100 \%)$ & $20(100 \%)$ \\
\hline $\begin{array}{l}\text { Income in INR/ } \\
\text { month } \\
0-1000 \\
1001-2000 \\
2001-3000 \\
>3000\end{array}$ & $\begin{array}{l}17(34 \%) \\
18(36 \%) \\
3(6 \%) \\
12(24 \%)\end{array}$ & $\begin{array}{l}\text { Mean income } \\
\text { INR } 2600\end{array}$ \\
\hline $\begin{array}{l}\text { Marital status } \\
\text { Single } \\
\text { Married }\end{array}$ & $\begin{array}{l}6(12 \%) \\
44(88 \%)\end{array}$ & $\begin{array}{l}3(15 \%) \\
17(85 \%)\end{array}$ \\
\hline \multicolumn{3}{|l|}{ Children } \\
\hline Have children & $43(86 \%)$ & $\begin{array}{l}\text { They did not allow our } \\
\text { kids to go to school. } \\
\text { They gave work to my } \\
\text { kids too. (Bonded } \\
\text { laborer, Nagiri) }\end{array}$ \\
\hline $\begin{array}{l}\text { Children } \\
\text { employed with } \\
\text { them }\end{array}$ & $31(70 \%)$ & $\begin{array}{l}\text { Some of the kids also } \\
\text { work with the parents } \\
\text { to pay off the debts. } \\
\text { They know no } \\
\text { schooling, no } \\
\text { education. (NGO } \\
\text { Director, Chennai) }\end{array}$ \\
\hline The nature of job & $\begin{array}{l}\text { Cleaning, } \\
\text { sweeping, } \\
\text { arranging } \\
\text { the rooms, } \\
\text { rice mills, } \\
\text { etc. }\end{array}$ & $\begin{array}{l}\text { The children are } \\
\text { denied their basic } \\
\text { rights; it is pathetic } \\
\text { that these people do } \\
\text { not even know such } \\
\text { rights exist for them. } \\
\text { (Government official, } \\
\text { Tamilnadu) }\end{array}$ \\
\hline
\end{tabular}

Tiruvallur $(n=6,36 \%)$ and Chengalpattu $(n=7,32 \%)$ districts of Tamilnadu and Nagiri $(n=7,32 \%)$. Key informants include: two directors from the international NGO, one government official, one aftercare manager and one field officer. The sociodemographic characteristics of the participants are summarized in Table 1. 
Table 2: Socio-economic conditions.

\begin{tabular}{|c|c|c|}
\hline Variable & Quantitative finding & Qualitative finding \\
\hline \multicolumn{3}{|c|}{ Amount of money that he owed } \\
\hline & $\begin{array}{l}\text { Unknown }=9(18 \%) \\
<5000=7(14 \%) \\
5001-10000=20 \\
(40 \%)\end{array}$ & $\begin{array}{l}\text { I don't know how much money I had to pay... My father was } \\
\text { working here and they made me work after him. (Bonded laborer, } \\
\text { Chengalpattu) }\end{array}$ \\
\hline & $\begin{array}{l}10001- \\
15000=12(24 \%) \\
>15000=2(4 \%)\end{array}$ & $\begin{array}{l}\text { I borrowed only } 5000 \text { rupees. They told me to work for few } \\
\text { months... it's been } 6 \text { years... still they are saying that I have to pay } \\
\text { interests.... (Bonded laborer, Nagiri) }\end{array}$ \\
\hline \multicolumn{3}{|l|}{ Reason for Borrowing } \\
\hline Day to day expenses & $45(90 \%)$ & $\begin{array}{l}\text { My wife was in hospital... I went to him (rice mill owner) for } \\
\text { money...he took my finger prints in some papers... and they told } \\
\text { that I have agreed to work for them to repay... it's been } 8 \text { years... } \\
\text { (Bonded laborer, Tiruvallur) }\end{array}$ \\
\hline $\begin{array}{l}\text { Special events } \\
\text { (marriages, wife } \\
\text { delivery, death, getting } \\
\text { back pawned jewels.) }\end{array}$ & $40(80 \%)$ & $\begin{array}{l}\text { One month I did not have enough money,.. one man took me to him } \\
\text { (Brick kiln owner)... he gave me money on high interest... one } \\
\text { month later.. They brought us as a family here.... They said that we } \\
\text { have to work for him to repay... it has been } 2 \text { years... (Bonded } \\
\text { laborer, Nagiri) }\end{array}$ \\
\hline $\begin{array}{l}\text { Number of years as } \\
\text { bonded labor }\end{array}$ & $\begin{array}{l}<1=3(6 \%) \\
1-5=29(58 \%) \\
>5=18(36 \%)\end{array}$ & e \\
\hline $\begin{array}{l}\text { Wages as a bonded } \\
\text { laborer }\end{array}$ & $\begin{array}{l}\text { Daily=31 }(62 \%) \\
\text { Monthly=9 }(18 \%) \\
\text { Never }=10(20 \%)\end{array}$ & - \\
\hline Daily wages $(n=31)$ & $\begin{array}{l}<100 / \text { day }=21(5- \\
100) \\
101-200=7 \\
201-300=1\end{array}$ & - \\
\hline \multicolumn{3}{|l|}{ Torture/Beaten up } \\
\hline Beaten up & $22(44 \%)$ & $\begin{array}{l}\text { Once I fought with my manager... they took hot iron rod and burnt } \\
\text { my thighs....(Bonded laborer, Tiruvallur) } \\
\text { In one argument.... They (mill owners)... raped my wife and beat } \\
\text { me up...(Bonded laborer, Chengalpattu) } \\
\text { Two days I was not given food and was beaten for trying to run } \\
\text { away from the mill...(Bonded laborer, Nagiri) }\end{array}$ \\
\hline \multicolumn{3}{|l|}{ Reasons for Going out } \\
\hline $\begin{array}{l}\text { Personal reasons like } \\
\text { marriage, death, etc }\end{array}$ & $22(44 \%)$ & $\begin{array}{l}\text { They allow us sometimes only in case of emergency like falling sick, } \\
\text { someone's death, etc.(Bonded laborer, Nagiri) }\end{array}$ \\
\hline $\begin{array}{l}\text { Getting the basic } \\
\text { necessities for living like } \\
\text { buying vegetables, flour, } \\
\text { and etc. }\end{array}$ & $45(90 \%)$ & $\begin{array}{l}\text { They used to allow us to buy basic things... like milk... } \\
\text { vegetables... etc...but we were not allowed to go very far. (Bonded } \\
\text { labourer, Chengalpattu) }\end{array}$ \\
\hline Never allowed & $5(10 \%)$ & $\begin{array}{l}\text { I was never allowed outside... I could not even go to nearby } \\
\text { villages....(Bonded labourer, Tiruvallur) }\end{array}$ \\
\hline \multicolumn{3}{|l|}{ Food habits } \\
\hline $1 \mathrm{meal} /$ day & $11(22 \%)$ & $\begin{array}{l}\text { They gave only one meal in morning before work... and one meal } \\
\text { after work at night.... (Bonded laborer, Nagiri) }\end{array}$ \\
\hline 2 meals/day & $35(70 \%)$ & $\begin{array}{l}\text { It had rice... it wont be cooked properly... we had found worms } \\
\text { once...(Bonded laborer, Chengalpattu) }\end{array}$ \\
\hline 3 meals/day & $4(8 \%)$ & $\begin{array}{l}\text { Some time they gave pulses... but that I very rare... rice is what we } \\
\text { eat... but low quality only....(Bonded laborer, Tiruvallur) }\end{array}$ \\
\hline $\begin{array}{l}\text { Water from Closed } \\
\text { sources }\end{array}$ & $34(68 \%)$ & $\begin{array}{l}\text { The water was from the local pond nearby... we used to get it from } \\
\text { the pond ourselves... that water only we used for } \\
\text { everything....(Bonded laborer, Tiruvallur) }\end{array}$ \\
\hline Water from open sources & $16(32 \%)$ & There was a large tank inside the mill.... We used the water for \\
\hline
\end{tabular}




\begin{tabular}{|c|c|c|}
\hline $\begin{array}{l}\text { Separate water for } \\
\text { drinking and ablution } \\
\text { purposes }\end{array}$ & $11(22 \%)$ & $\begin{array}{l}\text { cooking.. Drinking... washing... everything...(Bonded laborer, } \\
\text { Chengalpattu) }\end{array}$ \\
\hline $\begin{array}{l}\text { Working hours } \\
8-10 \text { hours/day }\end{array}$ & $1(2 \%)$ & $\begin{array}{l}\text { They used to wake up in the morning... before the rooster crows.... } \\
\text { Then we had to work all day... and only after sunset.. we stop } \\
\text { working and eat and sleep...(Bonded laborer, Chengalpattu) }\end{array}$ \\
\hline$>10$ hours/day & $49(98 \%)$ & $\begin{array}{l}\text { Even when I was sick once... they did not allow me to } \\
\text { rest...(Bonded laborer, Tiruvallur) }\end{array}$ \\
\hline $\begin{array}{l}\text { Sleeping hours } \\
<8\end{array}$ & $40(80 \%)$ & $\begin{array}{l}\text { We were always working.... They will not allow us to sleep... I was } \\
\text { beaten once for taking a nap...." (Bonded laborer, Nagiri) }\end{array}$ \\
\hline $\begin{array}{l}8-10 \\
>10\end{array}$ & $\begin{array}{l}8(16 \%) \\
2(4 \%)\end{array}$ & $\begin{array}{l}\text { My mill owner told me that I have to work a lot if I have to repay the } \\
\text { amount... he used to wake me up very early morning... even when } \\
\text { we are tired... they scold us... (Bonded laborer, Chengalpattu) }\end{array}$ \\
\hline $\begin{array}{l}\text { Major health problems } \\
\text { reported }\end{array}$ & $34(68 \%)$ & $\begin{array}{l}\text { We get hurt very often... sometimes due to heavy work... but } \\
\text { sometimes because our supervisors beat us up... especially when we } \\
\text { question them...(Bonded laborer, Tiruvallur) }\end{array}$ \\
\hline $\begin{array}{l}\text { Physical injury } \\
\text { Diseases }\end{array}$ & $16(32 \%)$ & $\begin{array}{l}\text { We all fall sick very often... we don't even go to a doctor... one of } \\
\text { my friends died because he had TB... but did not get treated on } \\
\text { time....(Bonded laborer, Chengalpattu) }\end{array}$ \\
\hline \multirow[t]{2}{*}{ Sanitary conditions } & $\begin{array}{l}\text { Good } 1=4(8 \%) \\
\text { Acceptable } 2=20 \\
(40 \%)\end{array}$ & $\begin{array}{l}\text { We did not have any clean places... our toilets were close to our } \\
\text { homes... sometimes the septic tanks will be very smelly...(Bonded } \\
\text { labourer, Nagiri) }\end{array}$ \\
\hline & $\begin{array}{l}\text { Bad } 3=2(4 \%) \\
\text { Poor } 4=6(12 \%) \\
\text { Worse } 5=18(36 \%)\end{array}$ & $\begin{array}{l}\text { We had lot of mice and bugs... it used to be stinky... the mice bite } \\
\text { all our things....(Bonded labourer, Tiruvallur) }\end{array}$ \\
\hline Type of house & $\begin{array}{l}60 \% \text { individual } \\
\text { rooms } \\
72 \% \text { very small } \\
60 \% 4-8 \mathrm{ppl} \text { in each } \\
\text { room }\end{array}$ & $\begin{array}{l}\text { We were } 7 \text { in our family... all of us stayed in that single small } \\
\text { room.... (Bonded laborer, Chengalpattu) } \\
\text { Each room had two to three families staying together... it was not at } \\
\text { all private (Bonded laborer, Nagiri) }\end{array}$ \\
\hline $\begin{array}{l}\text { Ventilation } \\
\text { No fan at all }\end{array}$ & $48(96 \%)$ & $\begin{array}{l}\text { We had a thatched roof... it had no lighting... no window... } \\
\text { nothing...(Bonded laborer, Tiruvallur) }\end{array}$ \\
\hline No window at all & $39(78 \%)$ & $\begin{array}{l}\text { We did not even have fans.... We used hand fans... but it was not at } \\
\text { all enough (Bonded laborer, Chengalpattu) }\end{array}$ \\
\hline Lighting & $76 \%$ poor & $\begin{array}{l}\text { We usually eat and sleep after sunset.... But even during day.... } \\
\text { Light was very scarce...(Bonded laborer, Tiruvallur) } \\
\text { There is very little light.... We had only a kundu bulb (small } \\
\text { bulb)....(Bonded laborer, Nagiri) }\end{array}$ \\
\hline $\begin{array}{l}\text { Social Recreation } \\
\text { Never }\end{array}$ & $28(56 \%)$ & $\begin{array}{l}\text { We did not have any sort of recreation... we talk among ourselves... } \\
\text { apart from that we had nothing...(Bonded laborer, Tiruvallur) }\end{array}$ \\
\hline At times & $22(44 \%)$ & $\begin{array}{l}\text { We were allowed to watch TV which was there in a common } \\
\text { hall...movies were never allowed....(Bonded laborer, Chengalpattu) }\end{array}$ \\
\hline History of caging & $8(16 \%)$ & $\begin{array}{l}\text { Once I fought with my supervisor... he put me in a cage... and no } \\
\text { food was given for five days... then I begged them... they released } \\
\text { me with warning....(Bonded laborer, Tiruvallur) }\end{array}$ \\
\hline $\begin{array}{l}\text { Number of days of being } \\
\text { caged }\end{array}$ & $14 \%>2$ weeks & 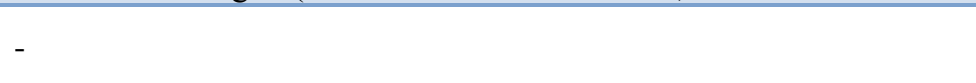 \\
\hline
\end{tabular}


The participants got bonded through various means. Most of them borrowing money for personal and family reasons. They were put in crowded rooms with poor ventilation and light. The food and sanitation is also not adequate from the perspective of the participants. Table 2 summarizes the socio economic conditions and illustrative quotes that expand on the quantitative findings.

Their health hazards largely depends on their working conditions, number of years as bonded labour, food and water, working hours, accommodation and their family size. They are totally deprived of the medical services. Sometimes they are forced to work even when they are ill. Only when the condition worsens, they allow them to go to hospital and that too in loss of pay. $92 \%$ of them are not at all aware of hypertension or diabetes mellitus. Table 3 summarizes the incidence of diseases or disorders of various systems.
Table 3: Incidence of ailments among the released bonded labourers.

\begin{tabular}{|ll|}
\hline System & $\mathbf{N}=\mathbf{5 0}$ (in \%) \\
\hline Height $<150 \mathrm{~cm}$ & $36(\mathrm{n}=18)$ \\
\hline Weight $<50 \mathrm{~kg}$ & $70(\mathrm{n}=35)$ \\
\hline BMI $<19$ & $32(\mathrm{n}=16)$ \\
\hline Diabetes mellitus/ Hypertension & $\mathrm{n}=3,6 \%$ \\
\hline Skin, hair \&nail & $\mathrm{n}=10,20 \%$ \\
\hline Visual problems & $\mathrm{n}=15,30 \%$ \\
\hline Respiratory problems & $\mathrm{n}=14,28 \%$ \\
\hline Mental health problems & $\mathrm{n}=1,2 \%$ \\
\hline Cardiovascular problems & $\mathrm{n}=9,18 \%$ \\
\hline Nervous system disorders & $\mathrm{n}=12,24 \%$ \\
\hline Gastrointestinal disorders & $\mathrm{n}=21,42 \%$ \\
\hline Sexually transmitted infections & $\mathrm{n}=2,4 \%$ \\
\hline
\end{tabular}

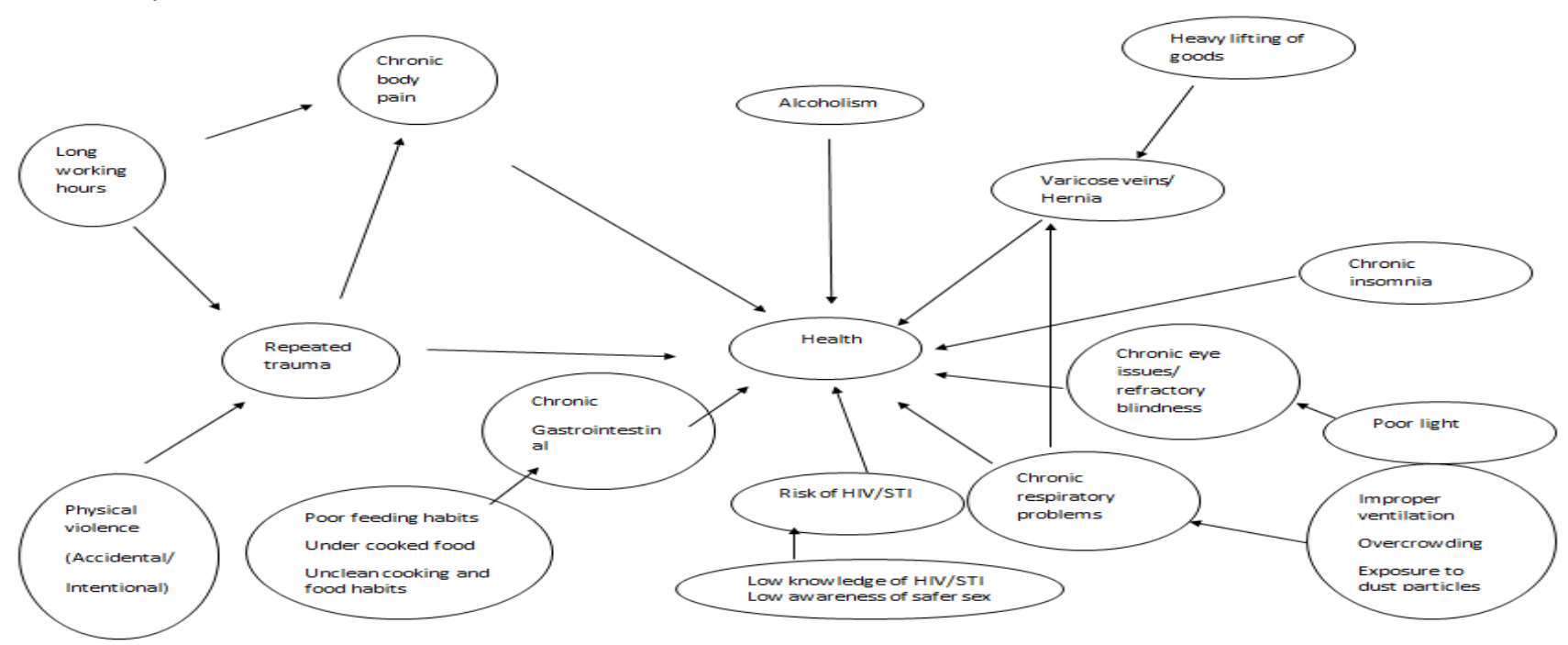

Figure 1: The various causative factors to their health.

\section{DISCUSSION}

Bonded labourers are a hard to reach population (Benach). ${ }^{7}$ They face numerous health hazards owing to their slavery (Muntaner). ${ }^{8}$ It is observed that they do not have acceptable living conditions with very low salary, poor sanitary conditions, and inadequate knowledge of healthy life styles and in access to health care providers (Benach). ${ }^{9}$ The health hazards depends upon the age, number of years as bonded labour, type of place of work (rice mill or brick kiln), knowledge about health services and access to health services. The pattern of age group distribution with high frequency between the ages 20 to 40 years is because the people who keep them bonded target the working population to get the maximum productivity from them. Moreover the people who take money from the owners tend to take it for family purposes like wife s pregnancy, children's studies, etc.
The income pattern largely depends upon the work they are engaged in. most of them work as sack lifters; wood cutters and construction workers post release.

A holistic approach was taken to cover up all the systems. Figure 1 shows the various causative factors to their health. The underlying problem of these people is in the access to health services. Even if they have any nearby government hospital or public health center, most of them do not go there due to lack of facilities, unethical treatment, etc.

Though they do not report much about skin, hair and nail disturbances, almost all of them are invariably affected by one or the other type of skin and hair disturbances. The skin diseases usually consist of eruptions and papules which can be attributed to the pond water which these people use for washing their genitals and taking bath. Usually this is an endemic. 
Comparing various variables, it is found that the relaxation of the terms of bondage is not at all related to their number of years as bonded labour. It largely depends on the nature of the owners.

The number of gastrointestinal problems is associated more with people who drink water from closed sources like tanks, drums, etc. It can be largely due to the unclean conditions of water storage.

The number of people who complained of worse ventilation had more incidences of respiratory diseases. This is augmented by overcrowding and absence of accessory ventilating systems like fans, etc.

The visual impairment is more with people who have been bonded for more years which recorded 8 cases for people who had worked for more than 5 years.

There is an indirect relationship between the family size and the health hazards. Having a large family meant that he has a heavier burden on him. So the debts would be more and the amount that can be repaid would be comparatively less than a person who has a smaller family. Secondly, whatever the size of the family may be, the size of the rooms was always the same. So a person who has a larger family would be having an overcrowded room, less food, poor ventilation, etc. Gastrointestinal problems have a higher incidence followed by the visual disturbances, respiratory complaints, nervous system problems and cardiovascular complaints. Most of them are not aware of Diabetes mellitus and blood pressure. All of them invariably have poor oral hygiene.

But their post release life has improved a lot. First of all, all of them have a great psychological sense of freedom. Secondly, the improved life style must have resolved the acute self-limiting illnesses. The health status of the women may be very poor compared to their counterparts which when documented would give a better about their occupation related health issues. Figure 1 shows the various causative factors to their health.

\section{CONCLUSION}

Structural and institutional policies are required to address the health issues of these bonded laborers. More studies are necessary to gain more insight on the health hazards faced by the bonded laborers of other parts of the country.

\section{ACKNOWLEDGEMENTS}

Author would like to thank International Justice Mission for their valuable support and inputs and also Dr. Seenivasan MD, Professor and Head of the Department, Department of Community Medicine, Stanley Medical College, Tamilnadu.

\section{Funding: No funding sources}

Conflict of interest: None declared

Ethical approval: The study was approved by the Institutional Ethics Committee

\section{REFERENCES}

1. 2014 Global Slavery Index.

2. International Labour Organisation. ILO 2012 Global estimate of forced labour: Executive Summary.

3. Kara S. Bonded labour: Tackling the system of slavery in South Asia. Columbia University Press. 2014.

4. Charmaz K. Constructing grounded theory: A practical guide through qualitative research. SagePublications Ltd, London. 2006.

5. Glaser B, Strauss A. The discovery grounded theory: strategies for qualitative inquiry. Aldin, Chicago. 1967.

6. Gibson W, Brown A. Working with qualitative data. Sage. 2009.

7. Benach J, Muntaner C, Chung H, Benavides FG. Immigration, employment relations, and health: Developing a research agenda. American Journal of Industrial Medicine. 2010;53(4):338-43.

8. Muntaner C, Solar O, Vanroelen C, Martínez JM, Vergara M, Santana V, et al. Unemployment, informal work, precarious employment, child labor, slavery, and health inequalities: pathways and mechanisms. International journal of health services. 2010;40(2):281-95.

9. Benach J, Solar O, Vergara M, Vanroelen C, Santana V, Castedo A, et al. Six employment conditions and health inequalities: a descriptive overview. International Journal of Health Services. 2010;40(2):269-80.

Cite this article as: Arunkumar A. Occupational health hazards and causative factors of male adult bonded labourers of South India: a mixed method pilot study. Int J Community Med Public Health 2016;3:735-40. 